\title{
SERVICE QUALITY AND ECONOMIC PERFORMANCE IN THE US AIRLINE BUSINESS
}

\section{Nicole KALEMBA ${ }^{1}$, Fernando CAMPA-PLANAS ${ }^{2}$, Ana-Beatriz HERNÁNDEZ-LARA ${ }^{3}$, Maria Victória SÁNCHEZ-REBULL ${ }^{4}$}

Department of Business Administration, University Rovira and Virgili,Avinguda Universitat 1, 43204 Reus, Spain

E-mails: ${ }^{1}$ nicole.kalemba@urv.cat (corresponding author); ${ }^{2}$ fernando.campa@urv.cat;

${ }^{3}$ anabeatriz.hernandez@urv.cat; ${ }^{4}$ mariavictoria.sanchez@urv.cat

Received 08 February 2017; accepted 07 September 2017
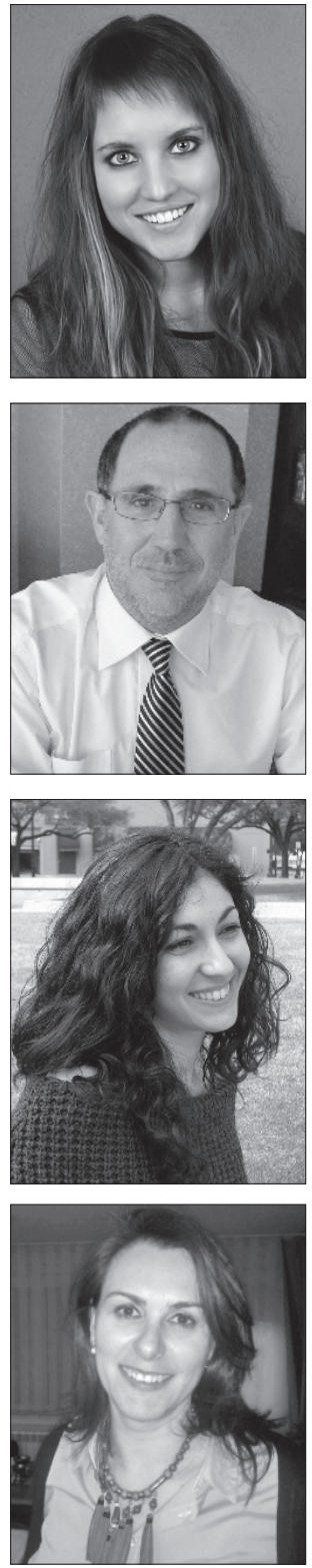

Nicole KALEMBA is a PhD Student and Research Assistant at the Department of Business Administration in the University Rovira and Virgili (Reus-Spain).

She has a Bachelor in Tourism Management and a Master's Degree in Analytical Techniques and Innovation in Tourism (University Rovira and Virgili), as well as a Master's Degree in Finance and Banking Management.

Her main field of interest is air transportation business.

Fernando CAMPA-PLANAS is a professor at the Department of Business Administration in the Universitat Rovira and Virgili (Reus - Spain).

The main fields of interest are management accounting, balanced scorecard and finance related with tourism, especially in the airline business and hospitality.

Before becoming dedicated to the University, he was Senior Vice-president Corporate Controller in Iberia Airlines and Chief Financial Officer in Port Aventura, a theme park managed by Universal Studios in Spain.

Ana Beatriz HERNÁNDEZ-LARA is a senior lecturer and Head of the Department of Business Management at Rovira and Virgili University (Spain). In 2007, she obtained her PhD at Pablo de Olavide University (Spain) with a thesis on the influence of corporate governance on innovation. Her research is related to corporate governance, innovation, internationalisation, tourism and e-learning. She currently participates in different research groups and projects on the internationalisation process and innovation strategies of Spanish firms and the effectiveness of e-learning methodologies in the learning process of university students.

Maria Victòria SÁNCHEZ-REBULL is an associate professor and the Director of the Department of Business Management at URV (Spain). She obtained her PhD at Rovira and Virgili University (Spain) in 2002; her thesis was on the implementation of activity based costing in the hotel sector. Her main research line is related to cost and management accounting and to the tourism and air transport sectors. 
Abstract. The purpose of this paper is to determine the effects of service quality on US airlines' economic performance.

In order to cover this goal, four quality indexes related to the airline industry, and two economic performance indicators, revenues and return on investment (ROI), have been considered. Data from American airline companies from 2006 to 2013 have been used to determine if airlines' profitability increases when service quality improves.

Considering the effects on airlines' profitability, the results confirm the positive and significant influence of service quality on the ROI of the US airline companies. A non-significant effect was found for airline revenues in relation to quality.

No previous research in this area has been done so these findings could encourage airline companies to invest in quality, since this policy can have a positive return on their profitability.

Keywords: air transportation, quality, airlines, economic performance, key performance indicators.

\section{Introduction}

During the last decades, the management of airlines has dramatically changed in order to become profitable and to survive, considering the big changes that occured in this business. Several factors such as legal deregulation, open skies policies, changes in the tourism model, introduction of revenue management policies, new infrastructures, new players as low cost carriers (LCCs), and high speed train competition (Albalate et al. 2014; MIT 2014) have had a considerable impact on the airline industry.

Since the legal deregulation of airlines in the USA in 1978, cost efficiency, operating profitability and competitive behaviour all became dominant issues facing airline management (Belobaba et al. 2009).

According to IATA (2015), the air traffic passenger demand is steadily growing, and it is expected that the airline sector will maintain these positive growth rates. The market share of the LCCs, in terms of passenger numbers, has grown significantly from 2\% in 1998 to $26 \%$ in 2013, while the growth of the flag carriers has been stagnant. This demonstrates that, in terms of absolute figures, the growth of the market has been due to LCCs (Eurocontrol 2013. However, despite the growth of the sector, it is not the same for all kinds of airlines. In general terms, passengers' demand between 2013 and 2017 is forecast to increase by $5.4 \%$ CAGR. Additionally, a slight increase will be maintained until 2030 (Statista 2015). This means that advancements in efficiency and technical processes are necessary; in fact they will only be possible if airlines reach their main objective - profitability, enabling them to survive in the long term.

Additionally, airlines are focused on improving the quality provided to passengers (and perceived by them) as a way to differentiate themselves from the competitors (Gursoy et al. 2005). Passenger satisfaction is one of the greatest assets that can be reached (Archana, Subha 2012; Akamavi et al. 2015), taking into account that a passenger who is not satisfied with the services offered by the airline will most likely become less reliable to continue its relationship with that airline.
The objective of this paper is, therefore, to determine and analyse the effect that service quality exerts on airlines' economic performance. To do so, we will determine the influence of four different airline related service quality indexes on the revenues and return on investment (ROI) considering a sample of US airline companies.

This paper is organized as follows. Initially, it describes the academic literature related to the concept of quality for airline companies, their profitability, and, finally, the potential relationship between quality and profitability. Section 3 describes the methodology applied, how data have been collected, and the variables of this study measured to test the relationship between quality and profitability. The final section presents a discussion on key findings and the main conclusions that can be drawn from this study.

Considering that the airline industry affects several sectors in the economy related to transportation, infrastructure, tourism, etc., this paper can be useful for managers, shareholders, stakeholders, and other people related to this industry, as well as for researchers in the airline sector.

\section{Conceptual framework and literature review on performance and quality in the airline industry}

\subsection{How to measure performance in the airline industry?}

Apart from the indicators that can be used by all industries (financial, non-financial, etc.), the airline business has its own specific Key Performance Indicators (KPIs) that have to be considered when analysing the performance of airline companies (Belobaba et al. 2009; Katz, Garrow 2014; Amat et al. 2011; MIT 2014).

One of the most specific and important KPIs of this business that will be used for the purpose of this study is the Load Factor, which has been analysed by different authors to identify its impact on the average operating costs per flight (Zuidberg 2014; Bilotkach et al. 2014). According to the Massachusetts Institute of Technology (MIT) (2014), the load factor is "the number of Revenue 
Passenger Miles (RPMs) ${ }^{1}$ expressed as a percentage of Available Seat Miles (ASMs)"2. It refers to the ratio of traffic to airline output, representing the proportion of airline output that is sold or consumed (Belobaba et al. 2009). As Zuidberg (2014) indicates, airlines can decrease their operating unit costs per passenger by maximizing their load factor, as an increasing load factor does not lead to relevant higher operation costs per aircraft movement. This means that airlines are able to get a higher profit if they increase their load factor, without the need to significantly increase operating costs. However, there are cost increases in fuel, catering, handling, among other factors that could represent an increase per seat, approximately $10-15 \%$ of the marginal revenue derived from this new seat being occupied (Doganis 2009). The load factor became a very important KPI, as long as the fares were public and small changes and discounts were applied; normally, there was a direct relationship between the load factor and the total revenues achieved by flight. Two other important KPIs that will be used in this study are the number of employees and passengers (PAX).

\subsection{How to measure quality in the airline industry?}

Providing a high-quality service to passengers in the airline business is necessary in order to retain customers and to achieve market-share and profitability (Morash, Ozment 1994; Hussain et al. 2015; Park et al. 2005; Doppelt, Nadeau 2013).

A relevant method for analysing airline service quality is the use of publicly available, secondary data, and indexes. Although the purpose of this paper is not to detail an exhaustive list of available sources, the most relevant indexes in the US are the following:

- American Customer Satisfaction Index (ACSI) which measures the satisfaction of the customers across the US economy. It is the "only national cross-industry measure of customer satisfaction in the US" and is based on customer evaluations about "the quality of goods and services purchased in the US and produced by domestic and foreign firms with substantial US market shares" (ACSI 2015);

- Wichita's Airline Quality Rating (AQR) that was developed in 1991 to possibly compare airline quality using performance criteria. The monthly taken rating is scores that are based on 15 elements in four major areas that focus on aspects of airline performance

\footnotetext{
1 RPM reflects how many of an airline's available seats were actually occupied.

2 ASM refers to one aircraft total seat flown one mile, whether occupied or not.
}

and allows comparing the performance of domestic airlines (AQR 2014);

- J.D. Power Airline Satisfaction Index, which measures the satisfaction of the passengers of US carriers considering seven criteria: costs and fees; in-flight services; boarding; deplaning and baggage; flight crew; aircraft; check-in, and reservations;

- Net Promoter Score (NPS) that is "a loyalty metric that is calculated by placing a company's customer into three categories: promoters, passives, and detractors" (Satmetrix 2014). It helps to improve customer service and to design a better customer experience.

\subsection{What has been said about quality in the airline industry?}

A literature review has been carried out using primarily the database Scopus, which permits us to find out and obtain academic journals and papers related to the topic.

For this literature review, we considered the period from 1993 to 2014, approximately when the open skies policy came into force, allowing airlines from then on to have more freedom to decide where to fly, to change fares easily, and to carry out new services.

The keywords used for the search were as follows:

- quality;

- service quality;

- air transportation;

- airlines;

- aviation.

These have been introduced in the database Scopus with the combinations: quality OR service quality AND air transportation OR airlines OR aviation, by searching through article title, abstract, keywords.

The results obtained through 11 different studies show 32 concepts related to service quality. Of the 32 concepts coming from the literature review, only 9 are quoted 3 or more times by the authors; they are as follows (with the number of quotations in brackets):

- punctuality (7);

- baggage handling (6);

- airline employees (5);

- handling of customer complaints and abnormal conditions (4);

- seat comfort (3);

- in-flight service (3);

- check-in service/process (3);

- food quality/service (3);

- reliability of service (3).

Table 1 has been developed to show a summary of the attributes used for measuring quality by the four selected quality indexes, which were explained previously. 
Table 1. Parameters mentioned by the literature and used by the four selected quality indexes

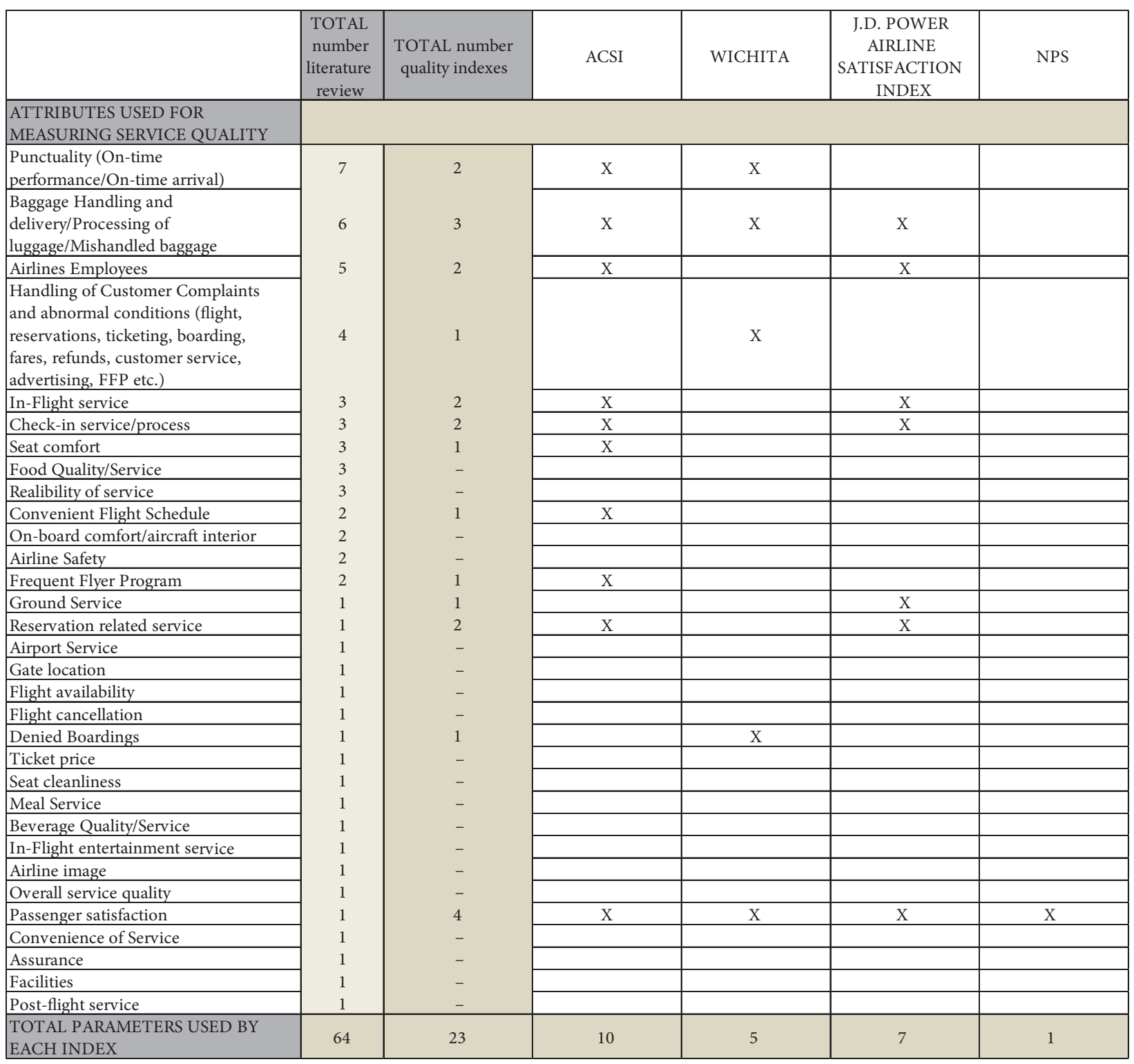

Source: created by the authors from the literature reviewed and mentioned as well as from the information coming from airlines' quality indexes.

While, based on the literature review, the most important parameters in previous research studies have been punctuality, baggage handling, and airline employees, Table 1 shows that the most important parameters included in those indexes are passenger satisfaction, followed by the baggage handling process. Although the quoted parameters of the literature review and the quality indexes do not seem to match, it has to be mentioned the advantage of the indexes is that they group together several criteria mentioned by the authors under the concept of "passenger satisfaction." Therefore, there are no significant differences between the parameters considered by the quality indexes and the academic literature.

\subsection{Is there any relation between profitability and quality?}

In the academic literature, a relation between the variable quality and the performance of a company has been identified, although different approaches have been applied when analysing the influence of quality on profitability.

The first approach considers the influence of the implementation of quality systems and the achievement of quality seals on the business results; meanwhile, the second approach focuses on the relationship between customer satisfaction indexes (CSI) and their impact on performance, measured internally by the company or valued externally by independent agencies. 
Thus, considering the first approach, it has been observed that the implementation of a total quality management system leads to advantages or improvements in the business results (Martínez Costa, Martínez Lorente 2008). This important approach helps to improve the service quality continuously and, therefore, to achieve higher customer satisfaction (Saravanan, Rao 2007). Although quality assessment from the perspective of customer satisfaction has been studied the most, there are also companies that certify the correct implementation of quality systems (ISO ${ }^{3}$, for example), which shows that these companies have a high positive impact in the stock market values (Nicolau, Sellers 2010).

The business management and performance of organizations who obtain these quality certificates is affected significantly (Bandyopadhyay, Kumar Das 2005; Hendricks, Singhal 1997).

Considering the second quality approach, which is focused on customer satisfaction indexes (CSI), studies in the academic literature suggest a positive relationship between customer satisfaction and a company's future profits taking into account such measures as the ROI and ROA (Zeithaml 2000; Bernhardt et al. 2000; Rust et al. 2002) as well as the net profit (Manafi et al. 2011).

According to Gould (1995) and Reichheld and Sasser (1990), customer satisfaction creates a repurchase intention and loyalty, which directly influences sales. For example, satisfied customers are less likely to move to competitors, and loyal customers are less likely to be price sensitive (Bowen, Chen 2001; Nam et al. 2011).

Clemes et al. (2011) showed that a successful delivery of customer satisfaction is an essential determinant for the long-term profitability of organizations (Zeithaml, Bitner 2003). However, it was also shown that there are components included in customer satisfaction that can have a negative relationship with the firm's profitability (Tornow, Wiley 1991). Kearney (1992) described a non-significant impact of the TQM in 80 percent of British firms.

According to Zeithaml (2000), other evidence and research findings related to the negative direct relationship between service quality and profitability have been studied by Easton (1993), Bounds et al. (1994), and Reger et al. (1994), among others. Zeithaml (2000) also indicated that, in some cases, due to the problems during the implementation of TQM systems the quality failed, consequently negatively affecting the firms' performance.

Therefore, we can conclude that, despite having found several studies that describe a negative relationship between profitability and quality, the majority of the studies reviewed, especially those related to hospitality, describe a positive relationship between both concepts

3 International Organization for Standardization.
(Nicolau, Sellers 2010; Clemes et al. 2011; Sun, Kim 2013). Although there are certain studies that outline the key aspects related to quality in airline transportation; however, to the authors' best knowledge, none of them analyse the relationship between quality and profitability. This literature gap drives us to the objective of this study - the analysis of the relationship between quality and the ROI as well as total revenues.

\section{Methodology}

\subsection{Sample collection and sources of information}

Two sources of information have been used for the study. For the financial ratios and airline KPIs, the Airline Data Project (ADP) built by the Massachusetts Institute of Technology (MIT) in the context of their Global Airline Industry Program was used. Data from 2006 to 2012 have been analyzed, because of their availability. The airline companies with available data that were included in this study are as follows:

- American Airlines;

- Continental, until 2011;

- Delta Airlines;

- Northwest Airlines, until 2009;

- United Airlines;

- US Airways;

- America West Airlines, until 2007;

- Southwest Airlines;

- JetBlue Airways;

- AirTran Airways;

- Frontier Airlines;

- Virgin America, since 2007;

- Hawaiian Airlines;

- Allegiant Air.

For quality, we included the following indexes where data has been obtained from their own public websites:

- American Customer Satisfaction Index;

- Wichita's Airline Quality Rating;

- JD Power's Airline Satisfaction Index;

- Net Promoter Score (NPS).

\subsection{Measurement of variables}

Two dependent variables, revenues and the ROI, are included to measure the firm's performance. Revenues show the total airline operations (scheduled and non-scheduled flights), including passenger, cargo, excess baggage and certain other transport-related operations. This variable, therefore, shows the income related to the number of passengers that have flown in a certain period of time. It is true that RM policies could imply that more revenue does not necessarily mean more passengers; greater revenues should contribute to better results shown in the profit and loss accounts. 
The second variable, the ROI, measures the return from an airline's assets. This KPI is very useful when comparing an airline's profitability, as it measures the relationship between the EBIT and total assets.

In the study, only one explanatory variable, the quality of the airlines, was used in our models. This variable was measured through the average of the standardized quality indexes. This criterion is based mainly on two factors. First, there is not enough data to calculate the correlation individually for each of the indexes. Secondly, no breakdown for all the variables used in each of the indexes is available, except for the Wichita index, where the four components are publicly available individually. Thus, we tried to summarize and simplify the quality variable under only one index.

For the analysis, we used three control variables to consider the effects of other variables not related to quality that can also affect an airline's performance, namely the load factor, the number of passengers, and the number of employees.

\section{Results}

All statistical analyses were carried out using the R, version 3.1.2 (The R Foundation 2014). The descriptive statistics and correlations of the variables used in the estimation models are provided in Tables 2 and 3 respectively.

As the correlation between company size variables is high, we suggest including only one company size variable to avoid problems of multicollinearity between the explanatory variables, so the logarithmic transformation of the number of employees is used as a general measure of the company's size (Le et al. 2006; Wu 2008; Hernández-Lara et al. 2014).
Given the unobservable firm-specific effects that could affect the dependent variables, the panel data methodology has been used in the estimation process. The empirical specifications proposed to respond to our hypotheses imply to run two regressions for the REVENUES and ROI respectively. The specifications of these two models were:

$$
\begin{aligned}
& \text { REVENUES }_{i t}=\beta 11 \text { Quality }_{\text {it }}+\beta 12 \text { Load factor }_{i t}+ \\
& \beta 13 \text { Size }_{i t}+\varepsilon_{i t}
\end{aligned}
$$

ROI $_{\text {it }}=\beta 21$ Quality $_{i t}+\beta 22$ Load factor $_{i t}+\beta 23$ Size $_{i t}+\varepsilon_{\text {it. }}$

The results for both models are provided in Table 4 . F tests and Hausman tests have been conducted to determine the choice between pooled OLS, fixed or random effects models. The most appropriate estimation method for the models depends on the properties of both the individual and the idiosyncratic errors (Croissant, Millo 2008).

In this case, the fixed effects model was the best estimation for Model 1; it means that the individual error is correlated with the regressors.

However, the pooled OLS was proven to be the most efficient estimator for $\beta$, because the individual component of error was missing altogether. Lagrange multiplier tests have also been conducted to determine the existence of individual and/or time effects based on the results of the pooling for Model 1 and 2.

The results confirm both individual and time effects for Model 1 (Lagrange multiplier test - two ways effects 8.285, $\mathrm{p}<0.001$ ) and for Model 2 (Lagrange multiplier test - two ways effects $15.010, \mathrm{p}<0.001)$.

Table 2. Descriptive statistics

\begin{tabular}{lcccc}
\hline \multicolumn{1}{c}{ Variables } & Min & Max & Mean & sd \\
\hline Revenues (R) & 0.020 & 38.29 & 10,096 & 10,028 \\
\hline ROI & -0.275 & 0.245 & 0.038 & 0.077 \\
\hline Quality (Q) & $-3,310$ & 1,642 & -0.042 & 0.907 \\
\hline Load factor (lf) & 0.621 & 0.909 & 0.819 & 0.042 \\
\hline Log PAX (lPAX) & 5,950 & 11,806 & 10,178 & 1,165 \\
\hline Log Employees (lEMP) & 6,735 & 11,385 & 9,562 & 1,303 \\
\hline
\end{tabular}

\begin{tabular}{|c|c|c|c|c|c|c|}
\hline Variables & $\mathrm{R}$ & ROI & Q & lf & IPAX & lEMP \\
\hline $\mathrm{R}$ & 1 & & & & & \\
\hline ROI & -.244 & 1 & & & & \\
\hline Q & -.391 & .414 & 1 & & & \\
\hline lf & .181 & .023 & .056 & 1 & & \\
\hline IPAX & .821 & -.254 & -.255 & -.152 & 1 & \\
\hline lEMP & .901 & -.314 & -.420 & -.021 & .955 & 1 \\
\hline
\end{tabular}

Table 3. Correlation matrix 
The results of the fixed effects estimation of Model 1 are provided in the first column of Table 4 . As the table shows, a non-significant effect was found for quality on airlines' revenues $(\beta 11=.044)$.

This means that the findings of this study do not confirm the positive influence of service quality on airlines' revenues. On the contrary, the effects of some control variables were as expected.

A positive sign of the coefficient for the control variables of load factor and size has been obtained: $\beta 12$ is positive $(\beta 12=.176 ; \mathrm{p}<0.01)$, and $\beta 13$ is also positive $(\beta 13=2.028 ; \mathrm{p}<0.001)$, which demonstrates the positive impact of the production/capacity ratio and company size on the airlines' revenues. It means that the incomes that the airlines receive from their normal business activities are higher in big companies with a high number of employees, and when their production is also high compared to their capacity. In contrast, better service quality does not seem to affect airlines' incomes directly.

It is important to mention that the revenues and the load factor do not need to necessarily have the same tendency, as those parameters depend on the size and stage of the aircraft. Therefore, the load factor can be higher in a short-haul route with less revenues than a route with a lower load factor and higher revenues.

Table 4 also provides a pooled OLS estimation of Model 2. Column 2 shows that, in this case, an airline's profitability is positively influenced by service quality $(\beta 21=.476 ; \mathrm{p}<0.001)$, as hypothesized, confirming that a better service quality perhaps does not affect an airlines' revenues but, in the end, improves the economic profitability of these companies. However, despite the confirmation of this result, a more limited value of the adjusted $R^{2}(0.238)$ suggests that there are some other

Table 4. Estimation models

\begin{tabular}{|c|c|c|c|c|}
\hline & \multicolumn{2}{|c|}{ Model 1 (fixed effects) } & \multicolumn{2}{|c|}{ Model 2 (pooling) } \\
\hline \multirow[t]{2}{*}{ Variables } & \multicolumn{2}{|c|}{ Dependent variable: REVENUES } & \multicolumn{2}{|c|}{ Dependent variable: ROI } \\
\hline & $\beta$ & $\mathrm{t}$ & $\beta$ & $\mathrm{t}$ \\
\hline Intercept & - & - & -.090 & -.782 \\
\hline Qualityit-1 & .044 & .693 & $.476^{* * *}$ & 3,498 \\
\hline Load factor ${ }_{i t}$ & $.176^{\star *}$ & 3,100 & .019 & .133 \\
\hline Size $(\text { lEMP })_{\text {it }}$ & $2.028^{* * *}$ & 13,321 & -.219 & $-1,460$ \\
\hline Hausman test (fix vs random) & $68.533^{* * *}$ & & $8.705^{\star}$ & \\
\hline F (pool vs fix) & $20.310^{* * *}$ & & 1,442 & \\
\hline Adjusted $\mathrm{R}^{2}$ & 0.610 & & 0.238 & \\
\hline $\mathrm{F}$ & $67.915^{\star * *}$ & & $7.334^{\star * *}$ & \\
\hline
\end{tabular}

All coefficients are standardized beta weights, and $\mathrm{t}$-values are also given.

${ }^{* * *} \mathrm{p}<0.001 ;{ }^{* *} \mathrm{p}<0.01 ;{ }^{*} \mathrm{p}<0.05 ;+\mathrm{p}<0.1$

Table 5. Estimation models: robustness checks

\begin{tabular}{|c|c|c|c|c|}
\hline & \multicolumn{2}{|c|}{ Model 1 (fixed effects) } & \multicolumn{2}{|c|}{ Model 2 (pooling) } \\
\hline \multirow[t]{2}{*}{ Variables } & \multicolumn{2}{|c|}{ Dependent variable: REVENUES } & \multicolumn{2}{|c|}{ Dependent variable: ROI } \\
\hline & $\beta$ & $\mathrm{t}$ & $\beta$ & $\mathrm{t}$ \\
\hline Intercept & - & - & -.081 & -.693 \\
\hline Quality $_{\text {it-1 }}$ & -.002 & -.036 & $.510^{* * *}$ & 3,988 \\
\hline Load factor $_{\text {it }}$ & .015 & .245 & -.013 & .930 \\
\hline $\operatorname{lPAX}_{\text {it }}$ & $3.010^{* * *}$ & 11,631 & -.235 & $-1,578$ \\
\hline Hausman test (fix vs random) & $47.906^{* * *}$ & & $10.644^{\star}$ & \\
\hline F (pool vs fix) & $23.768^{\star * *}$ & & 1,403 & \\
\hline Adjusted $\mathrm{R}^{2}$ & 0.572 & & 0.242 & \\
\hline $\mathrm{F}$ & $52.296^{\star * *}$ & & $7.487^{\star \star *}$ & \\
\hline
\end{tabular}

All coefficients are standardized beta weights, and $\mathrm{t}$-values are also given

${ }^{* * *} \mathrm{p}<0.001 ;{ }^{* *} \mathrm{p}<0.01 ;{ }^{*} \mathrm{p}<0.05 ;+\mathrm{p}<0.1$ 
relevant variables that are affecting the airlines' ROI and are not included in our model. The number of employees and the production/capability ratio do not have a significant effect on the airlines' economic profitability $(\beta 22=$ $.019 ; \beta 23=-.219$ ).

Additionally, some robustness tests have been conducted to check whether our findings regarding the influence of quality on economic performance are robust to alternative specifications of the models. The results of these tests are shown in Table 5; the company size is considered as the logarithmic transformation of the number of passengers, instead of the number of employees.

As Table 5 indicates, the results confirm what was stated above. A non-significant effect was found for quality on airlines' revenues $(\beta 11=-.002)$, although a positive and significant influence was proven for company size, measured as the number of passengers $(\beta 13=3.010$; $\mathrm{p}<0.001)$.

Considering the effects on airlines' profitability, the results confirm the positive and significant influence of service quality on the ROI of the companies in our sample $(\beta 21=0.510 ; \mathrm{p}<0.001)$.

\section{Discussion and conclusion}

Airline companies have been focused on the quality provided as a way to differentiate from their competitors (Gursoy et al. 2005; Chen, Hu 2013) by having a higher customer-oriented attitude and, therefore, improving their business performance.

Therefore, this research focuses on testing the outcomes of service quality on airlines' performance, in the case of US airlines. Four different well known and recognized indexes of service quality and two economic performance indicators have been considered, taking into account on one hand, the effects of service quality on airline revenues, and, on the other hand, the quality effect on economic profitability.

The results in both areas show a non-significant effect between quality and airline revenues, although a positive and significant influence was proven for company size, measured as the number of passengers.

Considering the effects on airlines' profitability, the results confirm the positive and significant influence of service quality on the ROI of the companies in our study. This result is even consistent and similar to previous studies related to hospitality and tourism management (i.e. Sun, Kim 2013), despite of the fact that the study has been developed exclusively for airline companies, using appropriate quality indexes and following a different research method.

Therefore, we consider that the statistical outcome can encourage airline management to continue improving service quality in their companies, since this would be a core competitive advantage for the development of any airline company. Airline managers should take this opportunity to contribute to the airline company's benefits and, therefore, respond to the political and economic transformations of recent years. This research also provides an important contribution to the academic community, especially for researchers in the airline sector.

However, this study has some limitations - only the US airlines have been included, and there is a lack of more data. Thus, non US companies could be included in further research, and more rating systems, such as Skytrax and Airline Ratings, with different sources to build their indexes could be used. Additionally, flag carriers and low cost carriers could be divided to open a new line of research in order to analyse if the obtained results are different.

\section{References}

Akamavi, R.; Mohamed, E.; Pellmann, K.; Xu, Y. 2015. Key determinants of passenger loyalty in the low-cost airline business, Tourism Management 46: 528-545.

https://doi.org/10.1016/j.tourman.2014.07.010

Albalate, D.; Bel, G.; Fageda, X. 2014. Competition and cooperation between high-speed rail and air transportation services in Europe, Journal of Transport Geography 22: 166-174.

Amat, O.; Campa-Planas, F.; Magaz, J. 2011. La Contabilidad de Gestión en las empresas de transporte aéreo. Asociación Española de Contabilidad de Empresas, AECA. 37 p.

ACSI. 2015. American customer satisfaction index [online], [cited 12 October 2015]. Available from Internet: http://www. theacsi.org/the-american-customer-satisfaction-index

Archana, R.; Subha, M. V. 2012. A study on service quality and passenger satisfaction on Indian Airlines, International Journal of Multidisciplinary Research 2(2): 50-63.

Bandyopadhyay, A.; Kumar Das, S. 2005. The linkage between the firm's financing decisions and real market performance: a panel study of Indian corporate sector, Journal of Economics and Business 57(4): 288-316. https://doi.org/10.1016/j.jeconbus.2004.11.005

Belobaba, P.; Odoni, A.; Barnhart, C. 2009. The global airline industry. John Wiley and Sons, Ed. https://doi.org/10.1002/9780470744734

Bernhardt, K. L.; Donthu, N.; Kennett, P. A. 2000. A longitudinal analysis of satisfaction and profitability, Journal of Business Research 47: 161-171.

https://doi.org/10.1016/S0148-2963(98)00042-3

Bilotkach, V.; Gaggero, A.; Piga, C. 2014. Airline pricing under different market conditions: evidence from European LowCost Carriers, Tourism Management 47: 152-163. https://doi.org/10.1016/j.tourman.2014.09.015

Bounds, G.; York, L.; Adams, M.; Ranney, G. 1994. Beyond Total Quality Management toward the emerging paradigm. New York: McGraw-Hill.

Bowen, J. T.; Chen, S. L. 2001. The relationship between customer loyalty and customer satisfaction, International Journal of Contemporary Hospitality Management 13(5): 213-217. https://doi.org/10.1108/09596110110395893

Chen, P. T.; Hu, H.-H. 2013. The mediating role of relational benefit between service quality and customer loyalty in airline industry, Total Quality Management \& Business Excellence 24(9-10): 1084-1095.

https://doi.org/10.1080/14783363.2012.661130 
Clemes, M.; Gan, C.; Ren, M. 2011. Synthesizing the effect of service quality, value, and customer satisfaction on behavioral intentions in the motel industry: an empirical analysis, Journal of Hospitality \& Tourism Research 35(4): 530-568. https://doi.org/10.1177/1096348010382239

Croissant, Y.; Millo, G. 2008. Panel Data Econometrics in R: The plm Package, Journal of Statistical Software 27(2). https://doi.org/10.18637/jss.v027.i02

Doganis, R. 2009. Flying off course IV: airline economics and marketing. Taylor \& Francis.

Doppelt, L.; Nadeau, M.-C. 2013. Making loyalty pay: lessons from the innovators, McKinsey on Payments, July 2013.

Easton, G. 1993. The 1993 State of U.S. Total quality management: a baldrige examiner's perspective, California Management Review 35(3): 32-54. https://doi.org/10.2307/41166742

EUROCONTROL. 2013. Market Segments in European Air Traffic 2013 [online]. European Organisation for the Safety of Air Navegation [cited 10 November 2015]. Available from Internet: www.eurocontrol.int

Gould, G. 1995. Why it is customer loyalty that counts (and how to measure it), Managing Service Quality 7(4): 4-26. https://doi.org/10.1108/09604529510796304

Gursoy, D.; Chen, M.-H.; Kim, H. 2005. The US airlines relative positioning based on attributes of service quality, Tourism Management 26: 57-67. https://doi.org/10.1016/j.tourman.2003.08.019

Hendricks, K.; Singhal, R. V. 1997. Does implementing an effective TQM program actually improve operating performance? Empirical evidence from firms that have won quality awards, Management Science 43(9): 1258-1274. https://doi.org/10.1287/mnsc.43.9.1258

Hernández-Lara, A. B.; Camelo, C.; Valle, R. 2014. Does board member stock ownership influence the effect of board composition on innovation?, European Journal of International Management 8(4): 355-372.

https://doi.org/10.1504/EJIM.2014.062956

Hussain, R.; Nasser, A.; Hussain, Y. 2015. Service quality and customer satisfaction of a UAE-based airline: an empirical investigation, Journal of Air Transport Management 42: 167-175. https://doi.org/10.1016/j.jairtraman.2014.10.001

IATA. 2015. International Air Transport Association [online], [cited 08 October 2015]. Available from Internet: http:// www.iata.org

Katz, D. S.; Garrow, L. A. 2014. Revenue and operational impact of depeaking at U.S. hub airports, Journal of Air Transport Management 34: 57-64. https://doi.org/10.1016/j.jairtraman.2013.07.011

Kearney, A. T. 1992. The cracks in quality, The Economist, 67-68.

Le, S. A.; Walters, B.; Kroll, M. 2006. The moderating effects of external monitors on the relationship between R\&D spending and firm performance, Journal of Business Research 59(2): 278-287. https://doi.org/10.1016/j.jbusres.2005.04.003

Manafi, M.; Gheshmi, R.; Hojabri, R.; Fotoohnejad, S. 2011. Mediating role of customer satisfaction in relationships between employee satisfaction and financial performance, Interdisciplinary Journal of Contemporary Research in Business 3(7): 782-794.

Martínez Costa, M.; Martínez Lorente, Á. R. 2008. Sistemas de gestión de calidad y resultados empresariales: una justificación desde las teorías institucionales y de recursos y capacidades, Cuadernos de Economía y Dirección de la Empresa 11(34): 7-30.

https://doi.org/10.1016/S1138-5758(08)70051-3
MIT. 2014. Global airline industry program [online]. Massachusetts Institute of Technology [cited 07 September 2015]. Available from Internet: http://web.mit.edu/airlinedata/ www/default.html

Morash, E. A.; Ozment, J. 1994. The augmented service offering for perceived and actual service quality, Journal of the Academy of Marketing Science 22(4): 352-363. https://doi.org/10.1177/0092070394224004

Nam, J.; Ekinci, Y.; Whyatt, G. 2011. Brand equity, brand loyalty, and consumer satisfaction, Annuals of Tourism Research 38(3): 1009-1030.

https://doi.org/10.1016/j.annals.2011.01.015

Nicolau, J. L.; Sellers, R. 2010. The quality of quality awards: diminishing information asymmetries in a hotel chain, Journal of Business Research 63(8): 832-839. https://doi.org/10.1016/j.jbusres.2009.06.009

Park, J. W.; Robertson, R.; Wu, C. L. 2005. Investigating the effects of airline service quality on airline image and passengers' future behavioral intentions: findings from Australian international air passengers, The Journal of Tourism Studies 16(1).

The R Foundation. 2014. The R project for statistical computing. $\mathrm{R}$ Development Core Team.

Reger, R. K.; Gustafson, L. T.; Demarie, S. M.; Mulland, J. V. 1994. Reframing the Organization: why implementing total quality is easier said than done, Academy of Management Review 19(3): 565-584.

Reichheld, F. F.; Sasser, W. E. 1990. Zero defections: quality comes to services, Harvard Business Review 68(10): 105-111.

Rust, R. T.; Moorman, C.; Dickson, P. R. 2002. Getting returns from service quality: revenue expansion, cost reduction, or both, Journal of Marketing 66: 7-24. https://doi.org/10.1509/jmkg.66.4.7.18515

Saravanan, R.; Rao, K. S. P. 2007. Measurement of service quality from the customer's perspective - an empirical study, Total Quality Management \& Business Excellence 18(4): 435-449. https://doi.org/10.1080/14783360701231872

Satmetrix. 2014. Satmetrix Data Product [online], [cited 24 October 2015]. Available from Internet: http://www.satmetrix.com

Statista [online]. 2015 [cited 12 March 2016]. Available from Internet: http://www.statista.com

Sun, K. A.; Kim, D. Y. 2013. Does customer satisfaction increase firm performance? An application of American Customer Satisfaction Index (ACSI), International Journal of Hospitality Management 35: 68-77. https://doi.org/10.1016/j.ijhm.2013.05.008

Tornow, W. W.; Wiley, J. W. 1991. Service quality and management practices: a look at employee attitudes, customer satisfaction, and bottom-line consequences, Human Resource Planning 14: 105-115.

AQR. 2014. Witchita's airline quality rating [online], [cited 12 October 2015]. Available from Internet: http://www.airlinequalityrating.com/

$\mathrm{Wu}$, H. L. 2008. When does internal governance make firms innovative?, Journal of Business Research 61: 141-153. https://doi.org/10.1016/j.jbusres.2007.06.010

Zeithaml, V.; Bitner, M. 2003. Service marketing: integrating customer focus across the firm. New York: McGraw-Hill.

Zeithaml, V. A. 2000. Service quality, profitability, and the economic worth of customers: what we know and what we need to learn, Journal of the Academy of Marketing Science 28: 67-68. https://doi.org/10.1177/0092070300281007

Zuidberg, J. 2014. Identifying airline cost economies: an econometric analysis of the factors affecting aircraft operating costs, Journal of Air Transport Management 40: 86-95. https://doi.org/10.1016/j.jairtraman.2014.06.007 